\title{
FRANCISCO JOSÉ GOMES DE SANTA ROSA: EXPERIÊNCIAS DE UM MESTRE PEDREIRO PARDO E PERNAMBUCANO NO OITOCENTOS
}

Marcelo Mac Cord ${ }^{*}$

$\mathrm{E}$ ntre os anos de 1830 e 1870, o Recife testemunhou expressivas mudanças conjunturais. Duas interessam ao meu artigo. A primeira delas foi a modernização espacial da cidade sob inspiração de elementos da cultura burguesa, projeto europeizante das elites letradas e proprietárias locais. Entre outros objetivos, essa classe social pernambucana queria dotar a capital da província com equipamentos urbanos considerados civilizados e "moralizar" seus canteiros de obras por meio da contratação de operários estrangeiros pretensamente disciplinados, civilizados e morigerados. ${ }^{1}$ A outra mudança foi o aumento da mão

* Professor da Universidade Federal Fluminense. E-mail: mmcord@uol.com.br

Aqui, faço especial referência à contratação de uma companhia de operários na Alemanha, que foi responsável pela construção de equipamentos urbanos para o recreio das elites letradas e proprietárias pernambucanas. Ao mesmo tempo, segundo a ótica dos contratantes, enquanto trabalhassem, os estrangeiros ensinariam à mão de obra local tanto novas técnicas de construção quanto valores vinculados à moral do trabalho burguês. O projeto ganhou efetivo impulso durante o governo conservador do barão da Boa Vista, entre finais da década de 1830 e princípios da seguinte. Para saber mais, consultar: Gilberto Freyre, Um engenheiro francês no Brasil, Rio de Janeiro: José Olympio, 1940; Guilherme Auler, A companhia de operários, 1839-1843: subsídios para o estudo da emigração germânica no Brasil, Recife: Arquivo Público Estadual, 1959; Raimundo Arrais, O pântano e o riacho: a formação do espaço público no Recife do século XIX, São Paulo: Humanitas/FFLCH/USP, 2004; Claudia Poncioni e Virgínia Pontual (dir.), Um ingénier du progrès: Louis-Léger Vauthier entre la France et le Brésil (Paris: Michel Houdiard, 2010). O projeto de "moralização" dos canteiros de obras por meio da contratação de trabalhadores europeus persiste nas décadas seguintes, com a chegada de artífices portugueses e belgas para as diversas oficinas dos arsenais pernambucanos. Códice AM-19, fls. 116-88 e 227, Arquivo Público Estadual Jordão Emerenciano (doravante APEJE), Recife, Setor de Documentos Manuscritos, Série Arsenal de Marinha; AM-20, fls. 151 e 173, APEJE, Recife, Setor de Documentos Manuscritos, Série Arsenal de Marinha. 
de obra livre em seu contingente populacional. O quadro demográfico pode ser justificado, entre outros fatores, pela constante desagregação do escravismo, pelos movimentos migratórios que se dirigiam do interior para a capital pernambucana e pelo tráfico interno, que transferiu muitos cativos para as províncias do sul. ${ }^{2}$ Ambas as mudanças conjunturais tinham potencial para ferir a empregabilidade dos mestres de obras recifenses que eram livres. Especialmente os que eram descendentes de africanos, foram formados nos canteiros locais e dominavam o mercado de edificações por conta de sua perícia. As mais antigas e consolidadas equipes da cidade que se destacavam nesse setor produtivo passaram a conviver em uma acirrada arena de disputas por trabalho e pela sobrevivência cotidiana.

Naqueles anos, as tensões entre monopólio e liberdade profissional, nos canteiros de obras da capital pernambucana, também fomentaram uma das mais curiosas batalhas contra a concorrência. Para os mestres de obras recifenses, que eram homens de cor pressionados pelas novidades, defender uma ou outra política de mercado dependia das conveniências políticas e econômicas. Em alguns momentos, eles eram favoráveis ao livre mercado, principalmente quando algum capitalista solicitava ao governo provincial o controle de sua indústria. Em outros, os mesmos profissionais defendiam o protecionismo de sua atividade, especialmente quando as próprias autoridades públicas autorizavam obras de edificação e reparo sob a supervisão de algum indivíduo sem a costumeira formação artesanal. Não bastassem tais vicissitudes, a contratação de novos serviços ainda exigia daqueles mestres de obras uma

\footnotetext{
2 Para compreender as referidas mudanças demográficas, consultar: Marcus Joaquim Maciel de Carvalho, Liberdade: rotinas e rupturas do escravismo, Recife, 1822-1850, Recife: Editora Universitária UFPE, 1998; Peter Louis Eisenberg, Modernização sem mudança: a indústria acucareira em Pernambuco, 1840-1910, Rio de Janeiro: Paz e Terra; Campinas: Editora da Unicamp, 1977; Robert Slenes, “The Demography and Economics of Brazilian Slavery" (Tese de Doutorado, Stanford University, 1976). Ao compararmos os censos pernambucanos dos anos de 1828,1856 e 1872, percebemos que, nesse interregno, a população do Recife cresceu $248 \%$. Em contrapartida, observamos que, proporcionalmente, a população cativa da cidade tendeu a diminuir sensivelmente. No censo de 1872 , foi declarado que a capital pernambucana tinha pouco mais de $10 \%$ de cativos em seu perímetro urbano. Carvalho, Liberdade; José Antônio Gonsalves de Mello (org.), Diário de Pernambuco e a história social do Nordeste (1840-1889), v. 2 (Recife: Diário de Pernambuco, 1975, p. 643); Marcelo Mac Cord, O Rosário de d. Antônio: irmandades negras, alianças e conflitos na história social do Recife, 1848-1872, Recife: FAPESP/Editora Universitária UFPE, 2005, pp. 29-30.
} 
sólida rede de relações pessoais com patronos poderosos. Afinal, em uma sociedade alicerçada na economia do favor, levava vantagem o artesão que dispunha de bons fiadores, contava com a confiança dos credores, era apoiado por influentes políticos e recebia informações privilegiadas sobre os orçamentos públicos. ${ }^{3}$

No Recife, a competição por serviços em nova conjuntura também exigiu que muitos dos velhos mestres de obras de pele escura reforçassem solidariedades baseadas em costumes comuns. ${ }^{4}$ No período em quadro, poderiam conseguir melhores níveis de proteção e de empregabilidade os trabalhadores que foram formados nas tradicionais culturas corporativas, conquistaram algum grau de instrução, estavam organizados em grupos de auxílio mútuo e conviviam em irmandades de ofícios - espaços que, antes da outorga da Constituição de 1824, desfrutaram do privilégio de diplomar artesãos, taxar preços e dizer quem poderia exercer as artes mecânicas que representavam. ${ }^{5}$ Reunidos por afinidades profissionais, familiares, religiosas, educacionais, culturais e étnicas, os mestres de obras recifenses, homens livres e descendentes de africanos, ainda combateram dois estigmas que rondavam suas vidas cotidianas. $\mathrm{O}$ da escravidão, que inferiorizava a mão de obra dos ex-cativos e de seus descendentes, classificando-a, por conta dos processos de racialização, como indisciplinada e inepta, e o do defeito mecânico, que era uma con-

3 Para saber mais sobre os conflitos entre protecionismo e liberdade no mercado das edificações recifenses, ver: Marcelo Mac Cord, Artífices da cidadania: mutualismo, educação e trabalho no Recife oitocentista, Campinas: Editora da Unicamp, 2012. Para uma discussão mais ampliada sobre o mercado de trabalho nos tempos do Império do Brasil, consultar: Alexandre de Freitas Barbosa, A formação do mercado de trabalho no Brasil, São Paulo: Alameda, 2008, pp. 91-160.

4 A categoria "costumes comuns" é fundamental para a reconstrução da trajetória de artífices especializados como Francisco José Gomes de Santa Rosa, que elaboraram suas identidades sociais por meio da convivência em associações de ofício e do compartilhamento de regras de conduta experimentadas no tirocínio artesanal - ou seja, nas oficinas, tendas e canteiros de obras. O trabalho artesanal de cunho mais tradicional, portanto, é indissociável de uma economia moral, nos moldes thompsonianos. Edward Palmer Thompson, Costumes em comum: estudos sobre a cultura popular tradicional. São Paulo: Companhia das Letras, 1998.

5 No Recife, antes da outorga da Constituição de 1824, que extinguiu oficialmente as corporações de ofício no país, a Irmandade de São José do Ribamar tinha o privilégio de proteger os interesses e os mercados de pedreiros, carpinteiros, tanoeiros e calafates. A Irmandade de São Crispim e São Crispiniano regulava a vida profissional dos sapateiros. A Irmandade de São Elói, Bispo, defendia os interesses e protegia os ourives de ouro e prata matriculados em suas fileiras. Francisco Augusto Pereira da Costa, "Estudo histórico-retrospectivo sobre as Artes em Pernambuco", Revista do Instituto Arqueológico, Histórico e Geográfico Pernambucano, n. 54 (1900), pp. 33-4. 
cepção coletiva que menosprezava todos aqueles que trabalhavam com as mãos - e, pretensamente, sem o auxílio do intelecto em suas atividades. ${ }^{6}$

Nas primeiras duas décadas recortadas por este texto, pelos menos duas importantes organizações recifenses estiveram atentas aos problemas e às questões que mobilizavam os mestres de obras recifenses, livres e de pele escura. Ambas operavam conjuntamente, apesar de autônomas. Além de compartilharem certos objetivos para a proteção daqueles profissionais, também eram compostas por membros comuns. Por vezes, encontramos, simultaneamente, um mesmo artesão ocupando importantes cargos deliberativos nas duas organizações. Uma delas era a Sociedade das Artes Mecânicas, uma associação mutualista muito parecida com suas congêneres europeias, onde os artífices especializados defendiam seus mais diversos interesses. ${ }^{7}$ A entidade recifense foi elaborada na década de 1830 e fundada em 1841, com a proposta de garantir auxílio financeiro aos sócios, de captar novos serviços no mercado e de promover sua instrução mais geral por meio de aulas noturnas. Em sua maior parte, os idealizadores do grupo de auxílio mútuo eram irmãos de São José do Ribamar, confraria que havia sido fundada em meados do século XVIII - e que ganhou o privilégio real de ser uma corporação de ofício nas últimas décadas da colonização portuguesa. Não por acaso, as duas

\footnotetext{
6 Atentos aos problemas que envolveram a emancipação dos cativos nas Antilhas, a pretensa inépcia dos africanos para a liberdade e para o trabalho livre foi muito bem explorada por Frederick Cooper, Thomas C. Holt e Rebecca J. Scott (orgs.), Além da escravidão: investigações sobre raça, trabalho e cidadania em sociedades pós-emancipação (Rio de Janeiro, Civilização Brasileira, 2005). O defeito mecânico, por sua vez, ajudou a construir a discutível inferioridade social do artesão. Ao hierarquizar e classificar as especializações profissionais, Aristóteles distinguiu as artes mecânicas como "menores" porque mercenárias. Nessa perspectiva, elas somente objetivavam a especulação financeira e a desonestidade. Na Idade Média, por sua vez, o defeito mecânico se associou ao tabu da impureza cristão. Os trabalhos que exigiam esforços físicos foram entendidos como herança do pecado original. Wilson de Oliveira Rios, "A lei e o estilo: a inserção dos ofícios mecânicos na sociedade colonial brasileira (Salvador e Vila Rica, 1690-1750)" (Tese de Doutorado, Universidade Federal Fluminense, 2000). Na perspectiva cristã, portanto, o defeito mecânico nos remete à maldição de Adão, que fez do trabalho manual um castigo de teor pedagógico. Ver Edward Palmer Thompson, A formação da classe operária inglesa: a maldição de Adão, v. 2, Rio de Janeiro: Paz e Terra, 2001.

7 Na primeira metade do século XIX, na Europa, observamos um fenômeno muito comum: a abertura de sociedades de auxílio-mútuo - ou de socorro mútuo ou mutuais. Entre outros objetivos, elas foram "formadas voluntariamente [para] promover auxílio financeiro a seus membros em caso de necessidade". Marcel van der Linden (ed.), Social Security Mutualism: the Comparative History of Mutual Benefit Societies (Bern: Lang), 1996, pp. 13-4.
} 
entidades que congregavam mestres de obras estiveram instaladas no templo em homenagem ao santo carpinteiro. ${ }^{8}$

Entre as décadas de 1850 e 1870, Sociedade e Irmandade disputaram poder e romperam relações. A primeira se instalou em nova sede e trouxe gente importante da política pernambucana para seu quadro de sócios honorários e beneméritos. Essas significativas mudanças aumentaram sua projeção pública. Contudo, é importante destacar que os artífices especializados de pele escura continuaram a controlar seus principais postos de poder. Naquele momento de transformação institucional, as aulas noturnas que a associação oferecia ganharam uma organização de caráter escolar e passaram a responder diretamente à Diretoria da Instrução Pública de Pernambuco. Apesar disso, os professores da casa também continuaram sendo os artífices descendentes de africanos, especialmente os que conseguiram frequentar estudos primários e secundários. No bojo desse processo, alguns sócios pretos e pardos, mestres qualificados pelos estudos teóricos e pelo tirocínio dos canteiros de obras, foram contratados para executar obras públicas - uma antiga reivindicação. O auge das conquistas da associação foi o direito de fundar e administrar o Liceu de Artes e Ofícios do Recife, além de criar uma empresa de edificações com o aval financeiro de grandes empreiteiros do setor. ${ }^{9}$

Atento às tensões e às complexidades que envolveram o mercado de edificações da capital pernambucana, aos desafios que precisavam ser enfrentados por determinados artífices nacionais de pele escura e àquelas duas organizações artesanais recifenses entre os anos de 1830 e 1870, o artigo que ofereço aos leitores faz parte de um esforço mais específico para rastrear as trajetórias de alguns sujeitos que se desta-

\footnotetext{
8 A problemática da reelaboração do repertório cultural corporativo pelas sociedades mutualistas foi muito bem analisada por Sewell Junior. Ao estudar o caso francês, o autor percebeu que os temas e os sentimentos compartilhados nas guildas fundamentaram a experiência organizativa de certos grupos de trabalhadores na primeira metade do Oitocentos. William H. Sewell Junior, Work \& Revolution in France: the Language of Labor from the Old Regime to 1848, Nova York, Cambridge University Press, 1982. Outros autores chegam a conclusões semelhantes, reforçando a importância das irmandades de ofícios na elaboração de sociedades mutualistas. Entre eles, podemos citar: André Gueslin, L'invention de l'économie sociale: idées, pratiques et imaginaires coopératifs et mutualistes dans la France du XIXe siécle, Paris: Economica, 1998, p. 146 ; Michel Ralle, "A função da proteção mutualista na construção de uma identidade operária na Espanha", Cadernos AEL: sociedades operárias e mutualismo, v. 6, n. 10/11 (1999), pp. 20, 25 e 36.

9 Para saber mais, ver Mac Cord, Artifices da cidadania.
} 
caram na vida da Sociedade e/ou da Irmandade, precisaram encontrar meios para consolidar sua cidadania e trabalharam para viver com mais prosperidade material. ${ }^{10}$ Francisco José Gomes de Santa Rosa foi um dos artífices pernambucanos que lutou para conquistar respeitabilidade pública, reconhecimento profissional e bons serviços nos canteiros de obras do Recife - mercado que preferencialmente oferecia os melhores contratos para aqueles que tinham reputação e contavam com substanciais redes clientelares. Junto disso, o mestre pedreiro pardo precisava superar muitos concorrentes estrangeiros e torcer para que os trabalhadores migrantes mais ou menos especializados fossem proletarizados. Por tudo isso, assim como propõe Edward Palmer Thompson, a vida de Francisco José Gomes de Santa Rosa e de seus companheiros esteve enredada por conflituosas relações entre contingências e vontade pessoal. ${ }^{11}$

\section{O destaque de Francisco José Gomes de Santa Rosa nas organizações dos mestres de obras pernambucanos}

Atento às conjunturas do período, e pressionado por elas, o mestre pedreiro Francisco José Gomes de Santa Rosa foi um dos protagonistas na luta em favor do artesão brasileiro, homem de cor qualificado no mercado de edificações pernambucano. Por meio de sua inserção social,

\footnotetext{
10 Ao finalizar minha tese, iniciei novas pesquisas para encontrar mais dados sobre alguns destacados artífices que passaram pela Irmandade e/ou Sociedade. É o caso, por exemplo, dos filhos do idealizador da Sociedade das Artes Mecânicas. Ver Marcelo Mac Cord, "Uma família de artífices 'de cor': os Ferreira Barros e sua mobilidade social no Recife oitocentista", Luso-Brazilian Review, v. 47, n. 2 (2010), pp. 26-48. Atualmente, tenho dedicado mais tempo à trajetória de um escultor pernambucano que havia sido escravo, conseguiu a alforria por causa de seu talento e foi estudar na Academia de Belas Artes da corte. Ver "Antonio Benvenuto Cellini: a trajetória de um escultor da escravidão à liberdade. Recife/Rio de Janeiro, século XIX”, Comunicação apresentada no VI Encontro Escravidão e Liberdade no Brasil Meridional, UFSC, 15-18 de maio de 2013. Disponível em <http://labhstc.ufsc.br/files/2013/04/Marcelo-Mac-Cord-texto. pdf $>$, acessado em 7/5/2013.

11 As tensões entre ação individual e condicionamento social são muito bem trabalhadas pelo marxista inglês, especialmente quando analisou, baseado em significativa pesquisa empírica, a formação da classe operária de seu país. Ver Thompson, A formação da classe operária inglesa, Apesar de fazer parte de outra tradição intelectual, sublinho a relevância da categoria "sociedade dos indivíduos" para a compreensão da trajetória do mestre de obras Francisco José Gomes de Santa Rosa. Forjada por Norbert Elias, ela faz um crítica aos estudiosos que propõem "sociedades sem indivíduos", cara aos marxistas mais ortodoxos, ou "indivíduos sem sociedade", bandeira dos liberais mais radicais. Ver Norbert Elias, A sociedade dos indivíduos, Rio de Janeiro: Jorge Zahar, 1994.
} 
ele ganhou destaque por exigir o reconhecimento público daquele trabalhador, sempre perseguido pelos estigmas da escravização e do defeito mecânico. Podemos acompanhar a atuação de Francisco José Gomes de Santa Rosa em dois importantes espaços de sociabilidades recifenses, que viabilizaram sua liderança junto aos artesãos. O primeiro deles é a Irmandade de São José do Ribamar, que reunia pedreiros, carpinteiros, tanoeiros e calafates. Não consigo precisar o ano de sua matrícula na entidade leiga, mas, por exemplo, em 1845, encontramo-lo no cargo de tesoureiro. Na mesma década, sabemos que havia ocupado o posto de juiz, o mais alto nível hierárquico da confraria. Segundo o Compromisso da Irmandade de São José do Ribamar, de 1840, podemos afirmar que Francisco José Gomes de Santa Rosa era perito em seu ofício. Somente os mestres daquelas quatro profissões que fossem brasileiros poderiam ocupar as cadeiras da mesa regedora, principal instância deliberativa da organização devotada ao santo carpinteiro. ${ }^{12}$

Na Sociedade das Artes Mecânicas, por sua vez, Francisco José Gomes de Santa Rosa matriculou-se em 1844. O Estatuto da sociedade mutualista informa que somente os mestres pedreiros e carpinas nascidos no país seriam aceitos como sócios. Tal informação confirma a reconhecida perícia do trabalhador pernambucano, que, no mesmo período, viabilizou a conquista de importantes cargos reservados aos mestres de ofício da Irmandade de São José do Ribamar. No Livro de Matrículas do grupo de auxílio mútuo, Francisco José Gomes de Santa Rosa surge como um pedreiro de 34 anos, homem pardo, casado, pernambucano e residente na Rua da Glória, que estava localizada na freguesia da Boa Vista. Vale destacar que, desde as reformas urbanas iniciadas pelo governo provincial, em finais da década de 1830, essa localidade recifense

\footnotetext{
12 Caixa 118P, maço religião, Assembleia Legislativa de Pernambuco (doravante ALEPE), Recife, Divisão de Arquivo, Série Petições. Caixa Irmandade de São José do Riba Mar — recibos, correspondências recebidas — anos 1850-1854, 1856-1859, maço 1850, Instituto do Patrimônio Histórico e Artístico Nacional (doravante IPHAN), Recife, Arquivo, Série Irmandade de São José do Ribamar. Compromisso ou Regulamento da Irmandade do Patriarcha o Senhor S. Jozé de Riba Mar, anno 1838, Instituto Arqueológico, Histórico e Geográfico Pernambucano (doravante IAHGP), Recife, Setor de Documentos Manuscritos, Estante A, Gaveta 15. O referido compromisso foi um documento elaborado em 1838, mas somente aprovado pelas autoridades competentes dois anos depois. Francisco Augusto Pereira da Costa, Anais Pernambucanos: 1740-1794, v. 6, Recife: Fundarpe, 1985, pp. 96-7 e 145-6.
} 
era conhecida como lugar de recreio e de moradia das camadas médias urbanas locais. Na sociedade de auxílio mútuo, por fim, o mestre pedreiro atingiu o mesmo destaque institucional que desfrutou na entidade religiosa devotada ao santo carpinteiro. Em 1845 e 1851, por exemplo, encontramos Francisco José Gomes de Santa Rosa ocupando a função de vice-secretário ou segundo secretário, que somente devia satisfações ao diretor e ao primeiro secretário. ${ }^{13}$

A importância de Francisco José Gomes de Santa Rosa em ambas as organizações, que possuíam semelhantes e restritivos critérios para a escolha de seus dirigentes, dialogou com suas vivências mais cotidianas, ligadas a sua vida privada. Não é possível entender o sucesso institucional do mestre pedreiro sem observar seu status pessoal. Da mesma forma, não podemos entender sua bem sucedida vida individual sem considerar o apoio de suas redes sociais. Afinal, ele conviveu em uma sociedade paternalista, que exigia um profundo envolvimento dos sujeitos em complexas relações coletivas, tecidas pelas conveniências cotidianas e pela economia do favor. ${ }^{14}$ Nesse sentido, é muito importante sublinhar que o perito era casado, condição fundamental para quem almejava respeitabilidade pública e a continuidade da tradição artesanal. O trabalhador era esposo de Engrancia do Amparo Santa Rosa, que gerou duas meninas: Amélia e Digna Santa Rosa. Os dados disponíveis não permitem afirmar que o patriarca tenha prometido a mão de suas filhas para artífices, que usufruiriam de seu legado. Entretanto, as relações

13 Livro de Matrícula dos Sócios, 1841-1859, fls. 44-5, Universidade Católica de Pernambuco (doravante UNICAP), Recife, Biblioteca/Coleções Especiais, Série Liceu de Artes e Ofícios. Caixa 118P, maço organização social e civil, ALEPE, Recife, Divisão de Arquivo, Série Petições. Caixa 122P, maço educação, ALEPE, Recife, Divisão de Arquivo, Série Petições. Sobre a freguesia da Boa Vista, entre outros, consultar: Leonardo Dantas da Silva, Recife: uma história de quatro séculos, Recife: Prefeitura da Cidade do Recife/Secretaria de Educação e Cultura, 1975; Orlando Parahym, Traços do Recife: ontem e hoje, Recife: Secretaria de Educação do Estado de Pernambuco, 1978; Flávio Guerra, "O Recife e o Conde da Boa Vista", in Arquivo Público Estadual de Pernambuco (org.), Um tempo do Recife (Recife: Editora Universitária UFPE, 1978); Vanildo Bezerra Cavalcanti, "O Recife e a origem dos seus bairros centrais", in Arquivo Público Estadual de Pernambuco (org.), Um tempo do Recife.

14 Sobre o paternalismo brasileiro, consultar as seguintes obras clássicas: Richard Graham, Clientelismo e política no Brasil do século XIX, Rio de Janeiro: Editora da UFRJ, 1997; Raymundo Faoro, Os donos do poder: formação do patronato político brasileiro, São Paulo: Globo/Publifolha, 2000; José Murilo de Carvalho, A construção da ordem: a elite política imperial; Teatro de sombras: a política imperial, Rio de Janeiro: Editora UFRJ/Relume-Dumará, 1996. 
construídas nos canteiros de obras foram fundamentais para proteger sua família. Na ocasião de sua morte, em fevereiro de 1861, Amélia e Digna foram tuteladas pelo mestre Francisco Martins dos Anjos Paula, companheiro de sociedade mutualista e de irmandade. ${ }^{15}$

É bastante interessante o fato de Francisco José Gomes de Santa Rosa surgir como pardo no Livro de Matrículas da sociedade mutualista. Não acredito que o registro significasse que o mestre de obras fosse um mestiço de pele mais clara. Ele representava sua posição social, tendo em vista o local de sua moradia, a constituição de uma família legítima, o exercício de um ofício especializado e o protagonismo em organizações artesanais. Até mesmo suas posses entravam na equação, já que o perito acumulou cabedais. ${ }^{16} \mathrm{Na}$ própria sociedade mutualista, é possível encontrar exemplos que sustentam minha hipótese sobre a cor preta de Francisco José Gomes de Santa Rosa. José Vicente Ferreira Barros era um mestre carpina preto. O trabalhador matriculou seus três filhos na associação, e todos surgiram como homens pardos, apesar de não serem mestiços. Isso permite afirmar que, na diacronia, a família alterou sua cor porque experimentou mobilidade social ascendente. Não por acaso, os jovens completaram o ensino secundário. Além de se tornar mestre de ofício, o filho mais velho, José Vicente Ferreira Barros Junior, foi professor público provincial. O mesmo ocorreu com o mais jovem, Antonio Basílio Ferreira Barros, que ainda cursou a Faculdade de Direito do Recife. João dos Santos Ferreira Barros foi um dos mestres de obras mais requisitados da cidade, além de presidir o Gabinete Artístico, órgão governamental para o fomento da indústria, e dirigir o Liceu de Artes e Ofícios. ${ }^{17}$

No período em que Francisco José Gomes de Santa Rosa foi gestor

15 Inventariado: Francisco José Gomes de Santa Rosa, Inventariante: Engrancia do Amparo Santa Rosa, caixa 144, TJR, fl. 8, IAHGP, Recife, Setor de Documentos Manuscritos. Assim como Francisco José Gomes de Santa Rosa, Francisco Martins dos Anjos Paula também foi um destacado membro da associação e da irmandade, ocupando, inclusive, postos de poder em ambas as organizações. Mac Cord, Artifices da cidadania.

16 Inventariado: Francisco José Gomes de Santa Rosa, Inventariante: Engrancia do Amparo Santa Rosa, caixa 144, TJR, fl. 8, IAHGP, Recife, Setor de Documentos Manuscritos. No transcorrer do artigo, explorarei os dados desse documento.

17 Mac Cord, "Uma família de artífices 'de cor"'. Respeitadas suas especificidades constitutivas, algumas pesquisas reforçam a relação entre mobilidade social ascendente, cor, liberdade, família e economia do favor nos tempos do escravismo brasileiro. Entre eles, consultar: Roberto Guedes, 
da Sociedade das Artes Mecânicas, uma de suas principais ações foi exigir que o governo provincial pagasse as subvenções que financiavam as aulas noturnas oferecidas pela sociedade mutualista - a Lei ${ }^{\circ} 130$ foi aprovada em 2 de maio de 1844 para que servisse de estímulo à indústria pernambucana, mas também ajudava os sócios a dissociarem suas imagens dos estigmas da escravidão e do defeito mecânico. Em uma petição de 21 de março de 1845, observamos que aquela ajuda, que havia sido aprovada por um ex-presidente conservador, estava sendo desconsiderada pelo governo dos Praieiros, que, curiosamente, defendia a nacionalização do comércio a retalho e o emprego do trabalhador local. ${ }^{18}$ Sem dúvida, a picuinha política pode ser apontada como um dos fatores para o bloqueio da subvenção, mas não era o único. Segundo Izabel Marson, os Praieiros procuraram instituir políticas que proletarizassem a mão de obra dos trabalhadores urbanos. Eles queriam transformá-los em "simples vendedores de força de trabalho e consumidores de mercadorias, absolutamente sem autonomia". ${ }^{19}$ Sem dúvida, isso era inaceitável para os artífices associados, que lutavam pela progressão de sua autonomia política e laborativa.

Além do pronto pagamento da subvenção anual regulada por lei, os gestores da Sociedade das Artes Mecânicas também exigiam o pronto aumento de seu valor, pois, segundo os peticionários, os governantes deveriam compreender melhor a função do Estado. Na ótica da sociedade mutualista, ele não deveria servir somente "às Armas, às Academias, à Magistratura e às grandes classes". Aquela instância de poder público deveria zelar pelo bem-estar de todos os cidadãos que tinham méritos. Por essa razão, ainda segundo o documento de 1845, a sociedade de auxílio

Egressos do cativeiro: trabalho, família, aliança e mobilidade social, Rio de Janeiro: Mauad, 2008; Zephyr L. Frank, Dutra's World: Wealth and Family in Nineteenth-Century Rio de Janeiro, Albuquerque: University of New Mexico Press, 2004. Podemos notar que tal relação foi fundamental nas histórias de vida de Francisco José Gomes de Santa Rosa e dos filhos de José Vicente Ferreira Barros. No Recife oitocentista, por fim, a manipulação da cor e das identidades étnicas, de acordo com as conveniências sociais, foi algo muito comum e bastante bem explorado por africanos e seus descendentes nas hierarquias do Rei do Congo, vinculadas à Irmandade de Nossa Senhora do Rosário dos Homes Pretos da freguesia de Santo Antônio. Mac Cord, $O$ Rosário de d. Antônio.

18 Caixa 118P, maço organização social e civil, ALEPE, Recife, Divisão de Arquivo, Série Petições.

19 Izabel Andrade Marson, O império do progresso: a Revolução Praieira em Pernambuco (18421855), São Paulo: Brasiliense, 1987, pp. 279-80. 
mútuo exigia medidas "por igual proteção", voltadas aos trabalhadores especializados que estavam nas camadas intermediárias da pirâmide social. Para pressionar os governantes pernambucanos, os artífices associados diziam que a justeza dessa medida evitaria "mais eficazmente a imoralidade e, com isso, a dissolução do Estado". ${ }^{20}$ De forma muito inteligente, o documento atribuiu ao Estado o papel de promotor da justiça social. Incluir os artesãos especializados na cidadania, reconhecendo seus talentos e virtudes, seria, portanto, uma boa forma de as elites letradas e proprietárias evitarem descontentamentos públicos.

Um ano depois, de forma mais suave e conciliatória, a sociedade de auxílio mútuo voltou a solicitar seu benefício pecuniário aos legisladores Praieiros e ao presidente da Província Antonio Pinto Chichorro da Gama - que era da mesma facção partidária. Mais uma vez, a subvenção anual surgia como lenitivo para que os sócios pudessem manter suas aulas noturnas e, assim, "suportar a concorrência estrangeira". O tom da petição de 1846 é mais diplomático, comparado com aquele do ano anterior. Em vez de acusarem o Estado de negligenciar os pagamentos da subvenção e a observância de sua função pública, os sócios disseram que "talvez por fatalidade [...] ficaram os pobres artistas esquecidos". Finalmente, os componentes da mesa diretora assinaram o documento apresentando "seus sinceros e respeitosos protestos de dedicação" aos governantes. Contudo, devo salientar que a mudança de atitude da sociedade mutualista não foi fruto de uma virada institucional de mesa, como se existisse uma nova gestão mais afeita aos políticos Praieiros. Prova disso é que, nas petições de 1845 e 1846, encontramos algumas assinaturas comuns, como, por exemplo, a de Francisco José Gomes de Santa Rosa. ${ }^{21}$

No final da década de 1840, quando os conservadores voltaram ao poder local, a sociedade mutualista ganhou maior projeção pública, por causa da aliança forjada desde a aprovação da subvenção. O grupo de artífices era uma das poucas referências para os governantes pensarem

20 Até aqui, Caixa 118P, maço organização social e civil, ALEPE, Recife, Divisão de Arquivo, Série Petições.

21 Até aqui, Caixa OR041, maço 1846, ALEPE, Recife, Divisão de Arquivo, Série Ofícios Recebidos. 
em políticas de "moralização" da mão de obra livre. Não por acaso, o projeto da Escola Industrial acabou dialogando com a experiência dos sócios. Por mais que esse estabelecimento tenha ficado no papel, o grupo de auxílio mútuo conseguiu conquistar, nos anos 1850, a função de seu mantenedor. Concorrentemente, ao comemorar seu décimo aniversário, a associação reformou seu Estatuto e mudou de nome: Sociedade das Artes Mecânicas e Liberais. Com isso, os artífices construíram ligações mais efetivas com membros das elites letradas e proprietárias, abriram suas matrículas para toda a classe artística e reafirmaram com mais ênfase sua qualificação teórica no exercício de seus ofícios. Por todas essas razões, encontramos muitos de seus mestres em obras governamentais e em escolas públicas. Na construção dessas estratégias institucionais, Francisco José Gomes de Santa Rosa foi um dos mais importantes idealizadores. Em 1856, por conta de seu protagonismo associativo, o pedreiro chegou à principal função da mesa diretora. ${ }^{22}$

Na década de 1850, Francisco José Gomes de Santa Rosa também ajudou a reorganizar a Irmandade de São José do Ribamar, pois compôs a comissão revisora do Compromisso de 1840. O sucesso institucional da Sociedade das Artes Mecânicas e Liberais - fruto da defesa de estudos teóricos para melhor execução dos ofícios, da construção de alianças com outras categorias da classe artística, da proximidade com as elites letradas e proprietárias e da montagem de um perfil organizacional mais afinado com a ideologia do progresso - criou novas demandas na tradicional entidade leiga. Alguns irmãos queriam se apropriar da experiência e do sucesso institucional da sociedade mutualista para reformar seu conjunto de regras, que ainda reproduzia aspectos mais familiares às velhas corporações de ofício - extintas legalmente pela Constituição

\footnotetext{
22 Para saber mais sobre as conjunturas que envolveram a sociedade mutualista na década de 1850 , ver, especialmente, o capítulo 2 de Mac Cord, Artífices da cidadania. Francisco José Gomes de Santa Rosa foi eleito diretor da Sociedade das Artes Mecânicas e Liberais em agosto de 1856. Livro de Atas do Conselho Administrativo da Sociedade das Artes Mecânicas e Liberais, 1855-1863, fl. 14, UNICAP, Recife, Biblioteca/Coleções Especiais, Série Liceu de Artes e Ofícios. Na década de 1850, o mestre pedreiro ainda ocupou os cargos de vice-diretor, em 1855, e de primeiro secretário, em 1852. Livro de Atas do Conselho Administrativo da Sociedade das Artes Mecânicas e Liberais, 1855-1863, fl. 7, UNICAP, Recife, Biblioteca/Coleções Especiais, Série Liceu de Artes e Ofícios. Livro de Atas do Conselho Administrativo da Sociedade das Artes Mecânicas e Liberais, 18521853, fl. 19, UNICAP, Recife, Biblioteca/Coleções Especiais, Série Liceu de Artes e Ofícios.
} 
de 1824. Além daquele mestre pedreiro, João dos Santos Ferreira Barros e José Vicente Ferreira Barros Junior, citados mais acima, artífices profundamente identificados com o grupo de auxílio mútuo, participaram da equipe revisora. ${ }^{23}$ No processo de revisão do Compromisso de 1840, a experiência associativa desses peritos foi determinante para reorientar a trajetória da Irmandade de São José do Ribamar, que perdia sua histórica hegemonia na condução das demandas de pedreiros e de carpinas.

Em 1856, mesmo ano em que foi eleito diretor da Sociedade das Artes Mecânicas e Liberais, Francisco José Gomes de Santa Rosa também conquistou o maior número de votos para o posto de juiz da Irmandade de São José do Ribamar. ${ }^{24}$ Parece evidente que o mestre pedreiro havia sido premiado por seus pares pela condução do processo de revisão do Compromisso. Além disso, podemos constatar que o artesão pernambucano, homem pardo, centralizou decisões em ambas as organizações artísticas, algo muito importante para quem desejava visibilidade pública e respeitabilidade em sua classe. Contudo, a construção dessa hegemonia não foi algo tranquilo. Na confraria, muitos irmãos que não eram sócios ficaram insatisfeitos com a crescente influência da sociedade mutualista no templo dedicado ao patriarca São José. Após a morte de Francisco José Gomes de Santa Rosa, seu aliado, João dos Santos Ferreira Barros, também acumulou, simultaneamente, os cargos de diretor e juiz. O que este último artesão chamou de "política de harmonia infinita" entre Sociedade e Irmandade gerou tantas insatisfações que, em 1866, o filho de José Vicente Ferreira Barros foi riscado da entidade leiga. Não satisfeitos, os irmãos contrários àquela política ainda despejaram a sociedade mutualista do Consistório Leste da Igreja de São José do Ribamar. ${ }^{25}$

${ }^{23}$ Livro dos Termos da Irmandade de S. José do Riba Mar, 1777-1854, fl. 78, IPHAN, Recife, Arquivo, Série Irmandade de São José do Ribamar.

${ }^{24}$ Livro dos Termos da Irmandade de S. José do Riba Mar, 1855-1869, fl. 10v, IPHAN, Recife, Arquivo, Série Irmandade de São José do Ribamar.

25 Para saber mais sobre as conjunturas que envolveram o despejo da sociedade mutualista do Consistório Leste da Igreja de São José do Ribamar, ver, especialmente, o capítulo 4 de Mac Cord, Artifices da cidadania. 


\section{Francisco José Gomes de Santa Rosa: perícia artesanal, penetração profissional e prestígio social}

Nas últimas décadas da Europa setecentista, a extinção das corporações de ofício foi uma política liberal que acabou com os privilégios dos mestres artesãos. O capitalismo promoveu a eliminação dos monopólios que eram desfrutados pelas oficinas. Na França, por exemplo, o Conservatoire des Arts et Métiers surgiu para ensinar ofícios para o maior número possível de pessoas, fazendo com que existisse mão de obra mais barata, disponível e com rápida formação. ${ }^{26}$ No Recife, por conta da falta de escolas do gênero, alguns irmãos de São José do Ribamar criaram a Sociedade das Artes Mecânicas, para que, por meio de suas aulas noturnas, conseguissem a mercê de diplomar seus membros em disciplinas como aritmética, arquitetura, primeiras letras e francês. A oferta de estudos teóricos seria uma forma de reinventar o monopólio das oficinas sobre novas bases e de demonstrar a civilização e o progresso de seus sócios, algo que garantiria algum capital simbólico para que se impusessem enquanto profissionais qualificados e cidadãos. Como apontei oportunamente, isso viabilizaria a relativização dos estigmas da escravidão e do defeito mecânico.

Atento às conjunturas e procurando construir sua própria história apesar das condições de seu tempo-espaço, Francisco José Gomes de Santa Rosa era um mestre pedreiro que tinha tenda aberta e trabalhava com risco próprio. Ou seja, o pernambucano possuía autorização pública para manter seu próprio negócio e a devida habilidade para planejar suas obras de edificação e de reparo. Sabemos disso porque, no Compromisso da Irmandade de São José do Ribamar, de 1840, o título de perito conferia, ao artífice especializado, a prerrogativa de ser um patrão que desenhava seus próprios projetos. Apesar desta última competência, Francisco José

\footnotetext{
26 Antônio Santoni Rugiu, Nostalgia do mestre artesão, Campinas: Autores Associados, 1998; João Tristão Vargas, "Qual é o liberalismo da Lei Chapelier? Seu significado para os contemporâneos e para a historiografia francesa dos séculos XIX e XX", Revista Mundos do Trabalho, v. 3, n. 5 (2011), pp. 213-32. Disponível em <http://www.periodicos.ufsc.br/index.php/mundosdotrabalho/article/viewFile/1984-9222.2011v3n5p213/19013>, acessado em 3/4/2012. Richard Stott, “Artisans and Capitalist Development", Journal of the Early Republic, v. 16, n. 2 (1996), pp. 257-71. Disponível em <http:/www.jstor.org/discover/10.2307/3124249?uid=3737664\&uid=2 \&uid=4\&sid=21102160253581>, acessado em 7/6/2007.
} 
Gomes de Santa Rosa foi aprofundar seus conhecimentos teóricos em arquitetura no grupo de auxílio mútuo, pois pretendia coordenar sua prática acumulada nos canteiros de obras com conceitos mais sistemáticos, algo que legitimaria sua maestria em bases consideradas mais modernas. Em 1851, encontramo-lo realizando os exames daquela disciplina, sendo aprovado plenamente pela banca. Em seguida, por causa de seu desempenho, um prêmio the foi oferecido pelas mãos do presidente da Província. No ano seguinte e devidamente diplomado, o ex-aluno foi contratado por seus consócios para a vaga de lente de arquitetura da Sociedade das Artes Mecânicas e Liberais. ${ }^{27}$

As aulas noturnas ministradas no Consistório Leste da Igreja de São José do Ribamar eram remuneradas, o que garantia alguma renda suplementar para Francisco José Gomes de Santa Rosa e seus colegas que eram lentes - exceto o professor de francês, todos os outros eram artífices de cor. Não é possível determinar o valor do salário que era pago ao corpo docente contratado pelo grupo de auxílio mútuo. Sabemos, entretanto, que a verba consignada pelo governo provincial era quase totalmente consumida pelas atividades pedagógicas. Na década de 1850 , o valor do crédito concedido anualmente pelas autoridades públicas montava a soma de 1:500\$000rs. Supondo, na pior das hipóteses, que pelo menos $60 \%$ desse total fosse distribuído entre as seis disciplinas oferecidas (primeiras letras, francês, geometria aplicada às artes, desenho linear, aritmética e arquitetura), cada funcionário receberia, aproximadamente, $150 \$ 000 \mathrm{rs}$, valor suficiente para qualificar o votante, cidadão ativo. A documentação ainda permite deduzir que Francisco José Gomes de Santa Rosa continuou ensinando aos artesãos até adoecer. A associação de artífices somente escolheu um novo titular para a disciplina pouco tempo depois de sua morte. Em 1862, João dos Santos Ferreira Barros, referido mais acima, filho do idealizador do grupo de auxílio mútuo, passou a regê-la. ${ }^{28}$

Ainda na primeira metade da década de 1850, Francisco José Gomes de Santa Rosa avaliou seus primeiros alunos (artífices associados), que foram plenamente aprovados nos exames. Em 1855, o

27 Livro de Atas do Conselho Administrativo da Sociedade das Artes Mecânicas e Liberais, 18521853, fls. 3v-4v, UNICAP, Recife, Biblioteca/Coleções Especiais, Série Liceu de Artes e Ofícios.

28 Para saber mais, ver o capítulo 2 de Mac Cord, Artifices da cidadania. 
mestre pedreiro ainda fez parte da comissão organizadora dos festejos que abrilhantariam as provas. Entre suas atribuições, os comissários deveriam convidar, para o evento, algumas pessoas que desfrutassem de prestígio no campo educacional pernambucano - para que se tornassem, inclusive, patronos da sociedade mutualista. No dia dos exames, participaram das festividades os professores Antonio Higídio da Silva, do Ginásio Provincial Pernambucano, e João Vicente Franco, do Colégio das Artes Preparatórias do Curso Jurídico. ${ }^{29}$ Ambos os estabelecimentos eram importantes escolas públicas secundárias. Naquele mesmo ano, o Ginásio Provincial Pernambucano havia sido inaugurado e substituiu o Liceu Provincial. Criado em 1832, o Colégio das Artes Preparatórias do Curso Jurídico foi produto do fim do Seminário de Olinda. Ainda em 1855, o estabelecimento de ensino havia sido transferido para o Recife. Não por acaso, todas essas mudanças foram fruto da reorganização da Diretoria da Instrução Pública de Pernambuco — processo iniciado no bojo da Reforma Couto Ferraz, que ocorreu na corte ${ }^{30}$

Até aqui, podemos notar que Francisco José Gomes de Santa Rosa acumulou muito poder e visibilidade na cidade do Recife, pois era destacado gestor da Sociedade e da Irmandade, cidadão respeitado e mestre de ofício com reconhecida perícia - tanto no tirocínio artesanal, quanto no domínio técnico e teórico de sua arte mecânica. Tais qualificações foram fundamentais para sua sobrevivência cotidiana, de sua família, de seus empregados e de seus protegidos. Do ponto de vista da empregabilidade em canteiros de obras, seu prestígio pessoal,

\footnotetext{
29 Livro para Termo de Exames no Liceu de Artes e Ofícios, fls. 1-3, UNICAP, Recife, Biblioteca/ Coleções Especiais, Série Liceu de Artes e Ofícios. Livro de Atas do Conselho Administrativo da Sociedade das Artes Mecânicas e Liberais, 1855-1863, fls. 4v e 12v, UNICAP, Recife, Biblioteca/ Coleções Especiais, Série Liceu de Artes e Ofícios.

30 Relatório que a Assemblea Legislativa Provincial de Pernambuco appresentou no dia da abertura da sessão ordinária de 1855, Recife: Typographia de Manoel Figueiroa de Faria, 1855, Fundação Joaquim Nabuco (doravante FUNDAJ), Recife, Setor de Microfilmes. Adriana Maria Paulo da Silva, "Processos de construção das práticas de escolarização em Pernambuco, em fins do século XVIII e primeira metade do século XIX" (Tese de Doutorado, Universidade Federal de Pernambuco, 2006), p. 228. Aprovada em 14 de maio de 1855, a Lei Provincial 369 reorganizou a Diretoria da Instrução Pública. Collecção de leis, decretos e resoluções da Província de Pernambuco, tomo XVIII, anno de 1855, Pernambuco: Typographia de M. F. de Faria, 1855 APEJE, Recife, Setor de Documentos Impressos. Vinicius Liode Pontes, “A Reforma Couto Ferraz e o estabelecimento de uma direção para a instrução primária e secundária no Império do Brasil" (Dissertação de Mestrado, Pontifícia Universidade Católica do Rio de Janeiro, 2009).
} 
seu conhecimento profissional e sua penetração naquelas duas organizações artísticas permitiram que o perito controlasse duas comissões que orçavam e distribuíam serviços para seus consócios e seus irmãos. Sem dúvida, isso era algo muito importante para garantir o pão diário de quem sobrevivia com o suor do próprio rosto, precisava de trabalho constante e de remuneração regular. Na sociedade mutualista, em 1852, observamos Francisco José Gomes de Santa Rosa compondo a Comissão de Obra de Pedreiro - ainda havia a de carpina e a de marcenaria. $\mathrm{Na}$ confraria recifense, também existiram organismos semelhantes, pois os irmãos que eram artífices também se preocupavam com a promoção de auxílios mútuos em sua igreja, mesmo que isso não fosse regulado pelo compromisso. ${ }^{31}$ Em 1855, por sua vez, nossa personagem foi nomeada para fazer parte da Oficina de Pedreiro - existia outra sob o controle da mesa regedora: a de carpinteiro. ${ }^{32}$

O domínio daquelas comissões, o reconhecimento público de sua perícia e as relações que foram construídas com as elites letradas e proprietárias pernambucanas permitiram que Francisco José Gomes de Santa Rosa abocanhasse uma série de empreitadas, que garantiam sua principal fonte de renda - as aulas noturnas que ministrava na associação apenas suplementavam-na, como comentei oportunamente. Posso oferecer ao leitor alguns exemplos de obras que foram executadas pelo mestre pedreiro. Em janeiro de 1857, a Câmara Municipal do Recife contratou o trabalhador especializado para escorar um sobrado demolido na Rua do Livramento. Meses antes, em setembro de 1856, a vistoria desse imóvel havia sido feita por Francisco Martins dos Anjos Paula, que, anos depois, como vimos, seria o tutor das filhas de Francisco

31 Alguns artigos dos compromissos que regulavam a vida institucional das irmandades nem sempre eram respeitados pelo corpo confraternal. Geralmente, eram imposições das autoridades competentes, sem muita relação com o cotidiano organizacional das entidades leigas. Concorrentemente, muitas práticas cotidianas consagradas pelo costume não eram previstas por esse tipo de documento. Os processos de romanização da Igreja Católica expurgaram práticas consideradas pouco piedosas dos compromissos, mas os costumes foram mantidos apesar de formalmente silenciados. Ver João José Reis, "Identidade e diversidade étnicas nas Irmandades negras no tempo da escravidão", Tempo, v. 2, n. 3 (1996), pp. 7-33. Ver Mac Cord, O Rosário de d. Antônio.

32 Livro de Atas do Conselho Administrativo da Sociedade das Artes Mecânicas e Liberais, 18521853, fls. 3v-4, UNICAP, Recife, Biblioteca/Coleções Especiais, Série Liceu de Artes e Ofícios. Livro dos Termos da Irmandade de S. José do Riba Mar, 1855-1869, fl. 3v, IPHAN, Recife, Arquivo, Série Irmandade de São José do Ribamar. 
José Gomes de Santa Rosa. ${ }^{33}$ É importante destacar que a contratação de ambos os artífices foi feita pela administração recifense. Antes da outorga da Constituição de 1824, era a municipalidade que ratificava as decisões corporativas da Irmandade de São José do Ribamar. Portanto, por mais que as corporações de ofício estivessem extintas na década de 1850 , os antigos costumes mantiveram próximos vereadores e mestres de obras que eram irmãos.

As relações costumeiras também foram muito importantes para que Francisco José Gomes de Santa Rosa, irmão de São José do Ribamar, fosse contratado para realizar empreitadas em irmandades recifenses. Situações desse tipo não foi fato incomum. Como demonstrei em meu último livro, Artifices da cidadania, as simpatias confraternais e a proximidade pela fé permitiram que muitos serviços de construção e de reparo, feitos no patrimônio das mais diversas entidades leigas pernambucanas, contassem com equipes compostas por devotos do santo carpinteiro - mas que também faziam parte da sociedade mutualista fundada por José Vicente Ferreira Barros. Nos anos de 1845 e 1846, por exemplo, a Irmandade de Santana contratou a mão de obra de Francisco José Gomes de Santa Rosa para ladrilhar a capela, os corredores e o adro da Igreja da Madre de Deus, onde estava sediada. Na mesma oportunidade, o trabalhador especializado ainda instalou canos e assentou uma grade de ferro no edifício sagrado - levantado pelos Oratorianos no século XVIII. Pelos serviços, foi cobrado aos contratantes o valor de 157\$980rs. Em 1848 , o perito retornou ao mesmo templo para realizar vários consertos, que foram orçados em $49 \$ 620$ rs. ${ }^{34}$

A proximidade de Francisco José Gomes de Santa Rosa com os leigos e com os vereadores recifenses também permitiu que laços fossem construídos com outras autoridades municipais. Em especial, os juízes de resíduos e de capelas, que, nas hierarquias judiciárias, julgavam casos de primeira instância e tinham autonomia para contratar artífices para vistoriar igrejas e demais propriedades das irmandades - fossem

\footnotetext{
33 Atas da Câmara Municipal do Recife, 1855-1858, fls. 61 e 84v, IAHGP, Recife, Setor de Documentos Manuscritos, Série Atas da Câmara Municipal do Recife.

34 Vera Lúcia Costa Acioli, A identidade da beleza: dicionário de artistas e artífices do século XVI ao XIX em Pernambuco, Recife: FUNDAJ/Massangana, 2008, pp. 220-1.
} 
móveis ou imóveis. Aos 13 de março de 1860, o doutor Francisco de Araújo Barros solicitou os serviços de três peritos para fazer uma vistoria na Igreja dos Prazeres, que enfrentava problemas no cumprimento de legados e demais obrigações. Dentre os mestres de obras que realizaram o serviço e receberam seus respectivos jornais, encontramos Francisco José Gomes de Santa Rosa e Francisco Martins dos Anjos Paula, que, como vimos mais acima, construíram alianças que extrapolavam os espaços de trabalho. Alguns anos depois, em 1863, a proximidade entre o juiz de resíduos e de capelas Francisco de Araújo Barros, Francisco José Gomes de Santa Rosa e Francisco Martins dos Anjos Paula possibilitou que o primeiro recebesse o título de sócio honorário da sociedade mutualista, mercê que somente era concedida àqueles pernambucanos que haviam colaborado com ela ou com seus membros. ${ }^{35}$

As compras de insumos é outro caminho para observarmos a movimentação de Francisco José Gomes de Santa Rosa pelos canteiros de obras da cidade do Recife. Vejamos dois exemplos mais pontuais, mas bastante representativos. No mês de dezembro de 1859 e no início do ano seguinte, o artífice realizou algumas compras na loja de Sebastião José da Silva. Pelo valor de 78 \$249rs, adquiriu, entre outros materiais de construção, fechaduras para armário, pregos franceses, dobradiças chatas, ferrolhos, dúzias de parafusos, pregos para assoalho e fechaduras comuns. Nesse caso, podemos inferir que Francisco José Gomes de Santa Rosa coordenaria serviços de carpina, pois instalaria portas, janelas, móveis e assoalho de madeira em alguma casa, sobrado ou prédio comercial. Por sua vez, nos meses de janeiro, março e abril de 1860, o artista mecânico de pele escura foi ao estabelecimento comercial de José Carneiro da Cunha. Em suas listas de compras, que contabilizaram o montante de $29 \$ 315 \mathrm{rs}$, constavam duas carroças carregadas com barro, 116 telhas, 500 tijolos de tapamento, 25 tijolos quadrados, 125 tijolos de ladrilho e

\footnotetext{
35 Lino do Monte Carmello Luna, "Memória sobre os Montes Guararapes e a Igreja de Nossa Senhora dos Prazeres, edificada em um delles, de que faz menção a acta supra", Revista do Instituto Archeologico e Geographico Pernambucano, n. 17 (1867), p. 275. Fernando Pio, "Artistas dos séculos passados", Revista da Escola de Belas Artes de Pernambuco, v. 3, n. 2 (1959), p. 15. Livro de Atas do Conselho Administrativo da Sociedade das Artes Mecânicas e Liberais, 1855-1863, fls. 74v, 75 e 77v, UNICAP, Recife, Biblioteca/Coleções Especiais, Série Liceu de Artes e Ofícios.
} 
dois alqueires de cal. ${ }^{36}$ Aqui, o perito preparava a edificação de algum tipo de cômodo residencial ou um simples depósito.

O prestígio social de Francisco José Gomes de Santa Rosa também pode ser medido nessas duas compras de material de construção, que foram realizadas em 1859 e 1860 . Nesse sentido, é preciso destacar que ambas foram feitas a crédito. As fontes indicam que Sebastião José da Silva e José Carneiro da Cunha eram estranhos aos quadros da Sociedade das Artes Mecânicas e Liberais. Provavelmente, também fossem aos da Irmandade de São José do Ribamar. Entretanto, apesar disso, ambos os comerciantes recifenses confiavam em um mestre pedreiro que era reconhecido por sua honorabilidade junto à classe artística e ao mercado de edificações. Sabemos que a concessão de créditos era algo muito significativo em uma sociedade marcada por relações pessoais, já que era de difícil acesso e dependia de uma série de fatores extraeconômicos - como relações de vizinhança, de amizade, de parentesco e de consanguinidade, por exemplo. Os poucos bancos existentes no Império do Brasil não atendiam às demandas financeiras e comerciais do grande público que buscava crédito, o que permitia aos particulares oferecerem dinheiro, serviços e produtos a juros. Em 1850, entre outros objetivos, o Código Comercial foi promulgado para regular tais práticas, muito comuns em sociedades patrimonialistas. ${ }^{37}$

\footnotetext{
36 Inventariado: Francisco José Gomes de Santa Rosa, Inventariante: Engrancia do Amparo Santa Rosa, caixa 144, TJR, fls. 14, 29-9v, IAHGP, Recife, Setor de Documentos Manuscritos, TJR, caixa 144.

37 Entre outros autores que se debruçaram sobre o assunto, consultar: Carlos Gabriel Guimarães, "Bancos, economia e poder no Segundo Reinado: o caso da Casa Bancária Mauá, McGregor \&Cia (1854-1866)" (Tese de Doutorado, USP, 1994); Francisco Iglésias, "Vida política, 1848-1866", in Sérgio Buarque de Holanda (dir.), História geral da civilização brasileira: o Brasil Monárquico, t. 2, v. 5 (São Paulo: Bertrand Brasil, 2004), pp. 17-139. Atenta ao Recife oitocentista, mas especificamente preocupada com a comunidade portuguesa envolvida com as mais diversas atividades comerciais, uma excelente pesquisa (com substancial base empírica) demonstra que a concessão de créditos e de empréstimos dependia de fortes relações pessoais. Ver Bruno Augusto Dornelas Câmara, “O 'retalho' do comércio: a política partidária, a comunidade portuguesa e a nacionalização do comércio a retalho, Pernambuco 1830-1870" (Tese de Doutorado, Universidade Federal de Pernambuco, 2012).
} 


\section{O padrão de vida e o legado de um mestre pedreiro que sobreviveu do seu trabalho}

As fontes que compulsei demonstram que Francisco José Gomes de Santa Rosa foi proprietário de quatro imóveis na freguesia da Boa Vista — avaliados em 15:500\$000rs. Um deles era uma casa térrea localizada na Rua dos Prazeres, 20. Em terreno próprio com 39 palmos de frente e 61,5 de fundo, a edificação tinha duas salas, dois quartos, duas gavetas, quintal murado (com portão para a Rua do Jasmim), dois cômodos (um para dispensa e outro para banho, cacimba, tanque e depósito de água), telheiro com estribaria e canteiro para flores. Outras três casas térreas estavam na Rua do Jasmim, 13, 15 e 17. Todas foram levantadas em terreno próprio com a mesma medida: 21 palmos de frente e $42,5 \mathrm{de}$ fundo. Em comum, possuíam duas salas, dois quartos, cozinha externa, cacimba e pequeno quintal murado. ${ }^{38}$ Em 26 de outubro de 1857, no Diario de Pernambuco, lemos uma crônica afirmando que a freguesia da Boa Vista era "uma residência deliciosa". Aquelas duas ruas, "mui novas", seriam ocupadas por boas casas térreas. Segundo a principal folha da província, notamos que os imóveis de Francisco José Gomes de Santa Rosa estavam em logradouros com vista agradável, voltados para "o lado poente, descobrindo uma parte do rio [Capibaribe] e outros pontos". 39

Descrito o patrimônio imóvel de Francisco José Gomes de Santa Rosa, faremos um breve parêntese. Recordemos que, em 1844, quando o mestre pedreiro iniciou sua vida associativa, havia informado que residia na Rua da Glória - localizada em mesmo bairro dos dois logradouros acima arrolados. Contudo, não é possível saber se o imóvel declarado à sociedade mutualista era alugado ou de sua propriedade, sendo posteriormente vendido. Além disso, não encontrei dados que permitam afirmar que o perito e sua família continuaram instalados no endereço revelado pelo Livro de Matrículas da Sociedade das Artes Mecânicas. De qualquer forma, podemos afirmar que a rua em questão era uma importante via da cidade, onde, inclusive, estava instalado o Convento

\footnotetext{
38 Inventariado: Francisco José Gomes de Santa Rosa, Inventariante: Engrancia do Amparo Santa Rosa, caixa 144, TJR, fls. 7-7v, IAHGP, Recife, Setor de Documentos Manuscritos.

39 "O bairro da Boa Vista e algumas palavras sobre a organização de uma correspondência predial nesta cidade", Diario de Pernambuco, 26 de outubro de 1857, FUNDAJ, Recife, Setor de Microfilmes.
} 
da Glória. Na referida crônica publicada no Diario de Pernambuco, em 26 de outubro de 1857, observamos que a Rua da Glória contava com 114 imóveis, sendo cinco de um andar, dois de dois andares e 107 casas térreas. Fechado o parêntese, podemos concluir que, residindo em qualquer uma das edificações até aqui citadas, a personagem que conduz este artigo habitou e organizou sua vida cotidiana em um bairro dedicado às camadas médias urbanas.

Nas fontes pesquisadas, encontramos alguns indícios de que a família Santa Rosa possuía um bom nível de consumo doméstico, o que ajuda a reforçar a percepção de seu status social. Em dezembro de 1859 e nos meses de março, abril e maio do ano seguinte, por exemplo, os membros da família compraram vários pares de borzeguins masculinos e femininos, que são botinas cujo cano se fecha por meio de cordões, e dois frascos de água de colônia. Os produtos custaram ao mestre pedreiro o total de 66\$000rs. As lojas de fazendas também eram frequentadas por Francisco José Gomes de Santa Rosa, esposa e filhas. Nos meses de abril e junho de 1859 , foram por eles adquiridos $94 \$ 660$ rs em peças de chita francesa, lenços para homem e chales de flores. A alimentação também exigia recursos, obviamente. Nos meses entre junho e outubro de 1860 , encontramos gastos parciais de $110 \$ 000$ rs em gêneros de primeira necessidade. No transcorrer dos anos de 1859 e 1860 , o pão que era consumido mensalmente por Francisco José Gomes de Santa Rosa, Engrancia, Amélia e Digna exigia mais um gasto médio de $12 \$ 000$ rs. Vez ou outra, eles também compravam biscoitos sortidos, o que exigia um dispêndio de $1 \$ 600$ rs em cada visita ao comércio. ${ }^{40}$

Os trabalhadores pobres que viviam no Recife estavam impossibilitados de sustentar tal nível de consumo doméstico. No Diario de Pernambuco de 25 de janeiro de 1858, encontramos um artigo intitulado "O futuro dos nossos artistas mecânicos. A Companhia de Aprendizes Menores do Arsenal de Marinha". O texto aplaudia os poderes imperiais pela organização do ensino profissional nesse tipo de estabelecimento militar. Especial menção mereceu o Arsenal de Marinha de Pernambu-

40 Inventariado: Francisco José Gomes de Santa Rosa, Inventariante: Engrancia do Amparo Santa Rosa, caixa 144, TJR, fls. 17, 20, 35 e 41, IAHGP, Recife, Setor de Documentos Manuscritos. 
co, que teria sido o primeiro do gênero "que tomou a iniciativa nesta circunstância". Por causa disso, segundo o articulista, muitas famílias pernambucanas, sem recursos, começaram a amenizar parte de suas dificuldades cotidianas mais básicas. Além de as oficinas militares proporcionarem aos meninos aprendizes "uma diária de 300rs para o seu sustento", também ofereciam "casa asseada", "comida abundante", "boa cama" e quatro "criados livres para os servir". ${ }^{41}$ Comparativamente, no Arsenal de Guerra de Pernambuco, em 1856, o custo diário da ração dos menores que aprendiam ofícios era de $\$ 400$ rs. De segunda a domingo, eles almoçavam, jantavam e ceavam em suas dependências. ${ }^{42}$

A partir desses dados concernentes à realidade de certos pernambucanos mais pobres, inferimos que uma criança das classes subalternas consumia, em víveres, na melhor das hipóteses, uma média mensal de 12\$000rs - valor que Francisco José Gomes de Santa Rosa e sua família gastavam somente com a compra do pão. Caso ela aprendesse um ofício especializado e levasse para sua casa algum dinheiro ao final da jornada de trabalho, poderia oferecer, também na melhor das hipóteses, uma ajuda mensal de 9\$000rs aos seus responsáveis. Ainda assim, caberia a estes últimos complementarem as necessidades nutricionais mais básicas do menor, caso tivessem condições para fazê-lo. Isso sem contar outras importantes demandas cotidianas. Caso fosse esse o padrão de vida médio das famílias pobres recifenses que utilizavam a força de trabalho de suas crianças, parece evidente que podemos sublinhar, mais uma vez, o fato de a família Santa Rosa viver com algum conforto. Reforça minha afirmativa o fato de as filhas do trabalhador especializado serem solteiras, menores e estarem somente ocupadas com os afazeres de seu lar - em atividades domésticas que aliviavam as responsabilidades cotidianas de Engrancia. ${ }^{43}$

41 "O futuro dos nossos artistas mecânicos. A Companhia de Aprendizes Menores do Arsenal de Marinha", Diario de Pernambuco, 25 de janeiro de 1858, APEJE, Recife, Hemeroteca. De fato, segundo o Regulamento da Companhia de Artífices do Arsenal de Marinha da Província de Pernambuco, aprovado aos 19 de abril de 1856, os menores matriculados tinham direito, entre outros regalos, a ração diária, roupas e algum pecúlio. Códice AM-16, fl. 227v, APEJE, Recife, Setor de Documentos Manuscritos, Série Arsenal de Marinha.

42 Códice AG-12, fls. 291-2, APEJE, Recife, Setor de Documentos Manuscritos, Série Arsenal de Marinha.

43 O fato de as filhas de Francisco José Gomes de Santa Rosa e Engrancia viverem em ambiente familiar, realizando afazeres domésticos junto de sua mãe, reforça também suas imagens de moças 
Apesar das evidências que ofereço ao leitor sobre a trajetória bem sucedida de Francisco José Gomes de Santa Rosa, outras significativas questões precisam ser consideradas. Estruturalmente, a vida profissional de um mestre de ofício era difícil e instável. Em alguns momentos, faltavam serviços no mercado de edificações. Em outros, as doenças e os acidentes de trabalho poderiam imobilizá-lo por longos períodos. Para diminuir os possíveis riscos advindos com o desemprego, vimos que o perito pernambucano, homem pardo, construiu boa reputação pública, teceu importantes redes de compromisso e ocupou espaços de poder e de privilégio em destacadas organizações da classe artística recifense. Compor os quadros do grupo de auxílio mútuo idealizado por José Vicente Ferreira Barros também oferecia a alternativa de pleitear apoios financeiros em prováveis momentos de vulnerabilidade, uma vez que nem sempre era possível fazer uma poupança pessoal para se prevenir de eventuais contratempos. ${ }^{44}$ Além disso, o perito viveu em uma sociedade em que os súditos de d. Pedro II precisavam ostentar publicamente suas posses, para que pudessem conquistar (e até mesmo manter) respeito e prestígio junto à coletividade.

honestas, segundo os padrões culturais recifenses do período. Para saber mais sobre a categoria "moças honestas" no Recife oitocentista, consultar: Maria Emília Vasconcelos dos Santos, “"Moças honestas' ou 'meninas perdidas': um estudo sobre a honra e os usos da justiça pelas mulheres pobres em Pernambuco Imperial (1860-1888)" (Dissertação de Mestrado, Universidade Federal de Pernambuco, 2007).

44 Estratégias desse tipo foram muito comuns no Império do Brasil. Na corte, por exemplo, as dificuldades securitárias e a instabilidade no mercado de trabalho foram fatores que motivaram operários, artesãos e ex-escravos a buscar apoio em associações de auxílio mútuo. Ver Ronaldo Pereira de Jesus e David Patrício Lacerda, "Dinâmica associativa no século XIX: socorro mútuo e solidariedade entre livres e libertos no Rio de Janeiro Imperial", Revista Mundos do Trabalho, v. 2, n. 4 (2010), pp. 126-42. Disponível em <http://www.periodicos.ufsc.br/index.php/mundosdotrabalho/article/view/1984-9222.2010v2n4p126/17235>, acessado em 11/12/2010. Na Bahia, por sua vez, novos estudos indicam quadro semelhante ao observado no Rio de Janeiro, onde as sociedades mutualistas também foram formadas para a proteção dos subalternos. Ver Aldrin A. S. Castellucci, "A luta contra a adversidade: notas de pesquisa sobre o mutualismo na Bahia (18321930), Revista Mundos do Trabalho, v. 2, n. 4 (2010), pp. 40-77. Disponível em <http://www. periodicos.ufsc.br/index.php/mundosdotrabalho/article/view/1984-9222.2010v2n4p40/17220>, acessado em 11/12/2010. A importância securitária das sociedades de auxílio mútuo pode ser observada até as décadas de 1930 e 1940, quando se consolidam as lutas por direitos sociais mais amplos e por sólida legislação trabalhista. Ver Cláudia Maria Ribeiro Viscardi e Ronaldo Pereira de Jesus, "A experiência mutualista e a formação da classe trabalhadora no Brasil", in Jorge Ferreira e Daniel Aarão Reis (orgs.), A formação das tradições (1889-1945) (Rio de Janeiro: Civilização Brasileira, 2007), pp. 21-51. 
Nos dois últimos anos de sua vida, por conta de uma doença crônica e das turbulências financeiras dela advindas, Francisco José Gomes de Santa Rosa precisou acionar suas redes sociais (compostas por artífices e por comerciantes) e seu prestígio pessoal para manter o padrão de vida de sua família. Para sustentar minha afirmativa, a primeira prova que ofereço ao leitor são as compras que foram realizadas pelo mestre pedreiro nos anos de 1859 e de 1860 . Recordemos que ele tomou fiado todos os materiais de construção arrolados mais acima. As outras compras (tecidos, roupas, sapatos, perfumes e mantimentos), realizadas na mesma época, também foram feitas da mesma forma. ${ }^{45}$ Sabemos que as referidas aquisições foram feitas a crédito porque a cobrança somente ocorreu quando da morte do mestre pedreiro, em fevereiro de 1861, como consta em seu inventário. Nesse documento, contudo, existem poucas dívidas que foram contraídas, junto ao comércio a retalho, antes do abalo da saúde do trabalhador especializado. É possível concluir, portanto, que nossa personagem conseguia honrar seus compromissos enquanto esbanjou vitalidade e permaneceu economicamente mais ativo na prática de seu ofício mecânico.

Ainda no transcorrer daqueles anos de saúde instável, Francisco José Gomes de Santa Rosa utilizou sua influência para conseguir dois empréstimos junto à Sociedade das Artes Mecânicas e Liberais. Somados, eles totalizaram 1:120\$000rs. A liberação de recursos mais vultosos era algo absolutamente extraordinário na sociedade mutualista, pois esse tipo de retirada exauria seus combalidos cofres - além da subvenção

\footnotetext{
45 A compra de roupas, por exemplo, era fundamental para a classe operária francesa oitocentista. "A dignidade da classe operária passa pelo 'bom aspecto' [...] uma roupa conveniente permite que [os operários] se misturem sem vergonha à festa urbana". Ver Michelle Perrot, Os excluídos da História: operários, mulheres e prisioneiros, Rio de Janeiro: Paz e Terra, 1988, p. 104. Outros exemplos reforçam essa questão. Na virada do século XIX para o XX, os caixeiros fluminenses procuravam se distinguir dos operários a partir do zelo com suas roupas. Ver Fabiane Popinigis, Proletários de casaca: trabalhadores do comércio carioca (1850-1911), Campinas: Editora da Unicamp, 2007, p. 46. Ainda na França de finais do século XIX, os trabalhadores militantes, para se distinguir dos demais, usavam la blouse et la casquette nas horas de lazer. Ver Eric J. Hobsbawm, Mundos do trabalho: novos estudos sobre história operária, Rio de Janeiro: Paz e Terra, 2000, p. 285. Comparativamente, tendo em vista o que sabemos sobre o mestre pedreiro Francisco José Gomes de Santa Rosa, parece que o mesmo se aplica à sua vida e de sua família, sempre ciosos de sua posição social e da manutenção de seu prestígio público. Reforça essa afirmativa o fato de as filhas do trabalhador especializado surgirem na sociedade recifense como meninas consideradas honradas, como vimos anteriormente.
} 
governamental, a tesouraria recebia mensalidades e joias pagas pelos sócios. Apesar dos apertos orçamentários, o grupo de auxílio mútuo ainda cometeu outro excesso quando da morte de seu ex-diretor. Ao oferecer pouco mais de $161 \$ 000$ rs para colaborar com seu enterro, os gestores extrapolaram os limites estabelecidos para esse socorro. Pouco tempo após as exéquias de Francisco José Gomes de Santa Rosa, por fim, outro favor incomum foi concedido a Engrancia, Amélia e Digna. No dia 21 de março de 1861, a viúva do mestre pedreiro pediu aos seus ex-consócios, reunidos em sessão ordinária, que perdoassem os juros daqueles empréstimos que haviam sido contraídos recentemente. A solicitação foi deferida. ${ }^{46}$ É provável que tais mercês levassem em conta os serviços que o perito prestou ao sucesso institucional da entidade artística.

Francisco José Gomes de Santa Rosa ainda recorreu a José Alves Barbosa para socorrê-lo. Com esse indivíduo, as dívidas do mestre pedreiro alçaram a considerável soma de 5:156\$000rs. Desse numerário, 4:500\$000rs correspondiam a uma hipoteca, 396\$000rs a compras fiadas e 260\$000rs a um pequeno empréstimo. Como podemos observar, o mestre pedreiro precisou comprometer parte do patrimônio imóvel de sua família, medida extrema que permitiu algum fôlego financeiro em momento de crise. Outro empréstimo menos substancial, mas representativo, no valor de 1:127\$088rs, foi pedido a Altino da Silva Leal. Nas fontes disponíveis, não foi possível identificar a relação de ambos os credores com o artífice especializado. De resto, percebemos uma infinidade de dívidas pulverizadas, de menor valor. No auto da partilha, computados os juros, os compromissos financeiros que foram herdados pela inventariante, Engrancia, chegaram ao impressionante total de 11:533\$989rs. Tendo em vista que o montante da fazenda foi de 16:255\$000rs, restaram apenas 4:721\$011rs para a viúva e suas duas filhas. Respectivamente, segundo as fontes, considerado este último valor, cada uma delas deveria receber $50 \%, 25 \%$ e $25 \%{ }^{47}$

\footnotetext{
${ }^{46}$ Inventariado: Francisco José Gomes de Santa Rosa, Inventariante: Engrancia do Amparo Santa Rosa, caixa 144, TJR, fl. 51, IAHGP, Recife, Setor de Documentos Manuscritos. Livro de Atas do Conselho Administrativo da Sociedade das Artes Mecânicas e Liberais, 1855-1863, fls. 33v-4 e 35v-6, UNICAP, Recife, Biblioteca/Coleções Especiais, Série Liceu de Artes e Ofícios.

47 Inventariado: Francisco José Gomes de Santa Rosa, Inventariante: Engrancia do Amparo Santa Rosa, caixa 144, TJR, fls. 4v, 82v-3v, IAHGP, Recife, Setor de Documentos Manuscritos.
} 


\section{Conclusão}

As herdeiras de Francisco José Gomes de Santa Rosa encontraram muitas dificuldades para pagar todas as suas dívidas. Além dos imóveis da freguesia da Boa Vista, o que foi deixado pelo mestre pedreiro era materialmente insignificante. Em seu inventário, nenhum dinheiro, ouro, prata ou escravos foram deixados para Engrancia, Amélia e Digna - joias e cativos podem ter sido negociados durante sua doença. Em abril de 1862, para piorar a situação, as casas de propriedade do artífice de pele escura não receberam nenhuma proposta mais significativa de compra, $o$ que postergava tanto a quitação dos compromissos financeiros da viúva, quanto o consequente usufruto do dinheiro que restasse. Exatamente um ano depois, em abril de 1863, esgotada a paciência/consideração de boa parte dos credores, foram expedidos mandatos de penhora das casas da Rua do Jasmim e da Rua dos Prazeres, já que elas continuavam sem compradores. O momento era tão crítico que, deferidas as solicitações, alguns ex-consócios de Francisco José Gomes de Santa Rosa propuseram que a associação de artistas mecânicos fosse mais condescendente com seus parentes, que estavam a ponto de perder a única casa que lhes restara. ${ }^{48}$

Deduzimos, por meio das fontes disponíveis, que Engrancia, Amélia e Digna foram obrigadas a experimentar muitas dificuldades financeiras e dissabores sociais após a morte de Francisco José Gomes de Santa Rosa. Não há dúvidas de que essas mulheres tiveram suas vidas absolutamente desestabilizadas, por conta da perda do patrimônio familiar e do paulatino esgarçamento das redes de favor que foram tecidas pelo mestre de obras - o que gerou, por exemplo, após dois anos de sua morte, a execução das dívidas contraídas. Junto dessas perdas, o fato de serem mulheres empobrecidas e de pele escura também deve ter acirrado, por sua vez, a precarização de suas liberdades - aprioristicamente, parto do princípio de que Engrancia também era descendente de africanos. ${ }^{49}$

48 Livro de Atas do Conselho Administrativo da Sociedade das Artes Mecânicas e Liberais, 18551863, fl. 87v, UNICAP, Recife, Biblioteca/Coleções Especiais, Série Liceu de Artes e Ofícios. Inventariado: Francisco José Gomes de Santa Rosa, Inventariante: Engrancia do Amparo Santa Rosa, caixa 144, TJR fls. 90, 92-5, IAHGP, Recife, Setor de Documentos Manuscritos.

49 Ao utilizar a categoria "precarização da liberdade" para compreender o que pode ter ocorrido com a família de Francisco José Gomes de Santa Rosa, após sua morte, não pensei na possibilidade de 
Como observamos no início deste artigo, os processos de racialização marcaram profundamente as relações sociais no Império do Brasil, especialmente quando as várias modalidades de exclusão procuravam abalar os corações e as mentes das pessoas com pele escura. Não quero dizer com isso que aquelas três pernambucanas foram passivas e aceitaram com tranquilidade os reveses do destino, mas, ao menos nos primeiros anos, sem a proteção do mestre pedreiro Francisco José Gomes de Santa Rosa, as conjunturas que envolveram suas vidas foram bastante desfavoráveis.

A trajetória do mestre pedreiro Francisco José Gomes de Santa Rosa, homem pardo pernambucano, permite que cheguemos a outras duas importantes conclusões. A primeira delas é que os artífices livres e qualificados, especialmente os descendentes de africanos, precisavam construir engenhosas estratégias tanto para garantir sua sobrevivência cotidiana quanto para conquistar prestígio socioprofissional — tendo em vista as barreiras sociais que lhes eram impostas por preconceitos étnicos, culturais, políticos e econômicos. Na cidade do Recife oitocentista, como vimos, tais estratégias utilizaram como insumo o associativismo e a instrução, elementos fundamentais para combater os estigmas da escravidão e do defeito mecânico. A outra constatação é que tais estratégias de inclusão e de mobilidade social ascendente eram constantemente ameaçadas pelas mais variadas vicissitudes. Por mais que os trabalhadores especializados desfrutassem de redes de favores, contassem com os socorros financeiros das sociedades mutualistas e contraíssem créditos junto aos comerciantes, longos períodos de convalescência, de desemprego crônico ou de poucos serviços contratados poderiam exaurir patrimônios que foram duramente acumulados no transcorrer de uma dura vida de labuta.

suspeição de suas liberdades (do ponto de vista jurídico) ou de reescravização. Não pensei também na perda de certos direitos conquistados. Em seus estudos de caso, essas formas de precarização da liberdade foram muito bem analisadas por Sidney Chalhoub, "Precariedade estrutural: o problema da liberdade no Brasil escravista (século XIX)", História Social: Revista dos Pós-Graduandos em História da Unicamp, n. 19 (2010), pp. 33-62. Disponível em <http://www.ifch.unicamp.br/ ojs/index.php/rhs/article/view/315/271>, acessado em 15/6/2011. A precarização da liberdade que proponho para Engrancia, Amélia e Digna vai ao encontro de formas de preconceito social e de discriminação racial que provavelmente sofreram por terem despencado na pirâmide social, o que certamente gerou várias formas de interdição cotidiana. 
Texto recebido em 24 de janeiro de 2013 e aprovado em 24 de junho de 2013

\begin{abstract}
Resumo
$\mathrm{O}$ artigo explora as experiências do mestre pedreiro e homem pardo Francisco José Gomes de Santa Rosa, que viveu entre os anos de 1810 e 1861. Por meio de livros de associações de artífices especializados e de seu inventário, entre outros documentos, que foram compulsadas nos mais diferentes arquivos recifenses, observamos que o trabalhador foi homem livre, pernambucano, casado, proprietário de alguns imóveis e ganhou destaque em duas organizações dedicadas aos profissionais de seu ofício. Por conta de suas redes de clientela, de seu destaque junto à classe artística e do reconhecimento público de sua perícia, José Francisco Gomes de Santa Rosa alcançou alguma instrução, acumulou cabedal e constituiu uma boa rede de relações. No final de sua vida, contudo, por conta de uma doença crônica e da manutenção de seu padrão de vida (à custa do esgotamento de seus recursos), o artesão de pele escura deixou sua família materialmente desamparada.
\end{abstract}

Palavras-chave: artesão - mutualismo - irmandade

\begin{abstract}
The article explores the experiences of a brown-skinned master mason named Francisco José Gomes de Santa Rosa, who lived from 1810 to 1861. By means of specialized craftsmen associations' books and his inventory, among other documents, which were scrutinized in the various files in Recife, we observed that he was a free man from the state of Pernambuco, married, owner of a few pieces of real estate and gained prominence in two organizations dedicated to the professionals of his craft. On account of his network of customers, of his prominence with the artistic class and the public acknowledgement of his skill, Francisco José Gomes de Santa Rosa achieved a certain level of education, accumulated assets, and put together a good network of relations. At the end of his life, however, on account of a chronic disease and the maintenance of his living standards (at the cost of depleting his resources), the dark-skinned craftsman left his family materially deprived.
\end{abstract}

Keywords: craftsman - mutualismo - brotherhood 